\title{
HUBUNGAN STATUS GIZI TERHADAP KEBUGARAN JASMANI PADA SISWA SEKOLAH MENENGAH ATAS NEGERI 10 MERANGIN
}

\author{
${ }^{1}$ Sukendro \\ ${ }^{2}$ Isnia Zulfa \\ Correspondence: Fakultas Ilmu Keolahragaan Universitas Jambi, Jambi, \\ Indonesia \\ E-mail: sukendrodasar@yahoo.co.id
}

\begin{abstract}
Abstrak
Tujuan dari penelitian ini dilakukan adalah untuk mengetahui hubungan status gizi terdapat kebugaran jasmani pada Siswa Sekolah Menengah Atas Negeri 10 Merangin. Variabel dalam penelitian ini adalah variabel bebas $(x)$ status gizi dan Variabel terikat (y) lari 1000 meter. Sampel yang diambil dalam penetian ini yaitu siswa kelas X SMAN 10 Merangin. Metode penelitian yang digunakan adalah metode korelasi dengan jumlah sampel 30 orang dari sebagian jumlah populasi yang berjumlah 136 orang. Sampel didapatkan dengan teknik random sampling. Hasil perhitungan analisis data kaidah keputusan jika $t_{\text {hitung }}>t_{\text {tabel }}$ berarti signifikan, sebaliknya jika $t_{\text {hitung }}>t_{\text {tabel }}$ berarti tidak signifikan, berdasarkan hasil yang didapat $t_{\text {hitung }}$ 10,9840 dengan $t_{\text {tabel }} 1,70113$ dengan demikian $t_{\text {hitung }}$ lebih besar dari $t_{\text {tabel }}$ maka dapat disimpulkan bahwa terdapat hubungan kebugaran jasmani menggunakan lari 1000 meter dan status gizi pada siswa SMAN 10 Merangin. Dengan demikian dapat disimpulkan terdapat hubungan status gizi terhadap lari 1000 meter pada siswa SMAN 10 Merangin.
\end{abstract}

Kata Kunci: Status Gizi, Kebugaran Jasmani

\section{Pendahuluan}

Untuk memelihara berat badan yang ideal, menjaga kesehatan, kebugaran jasmani dan melakukan perkerjaan sehari-hari, kita perlu memilih makanan yang tepat dengan jumlah yang tepat. Kelebihan gizi dapat menyebabkan kegemukan, obesitas (kegemukan) >20\% dari berat badan ideal dapat menyebabkan hipertensi, struk, penyakit jantung, dibetes ginjal, gangguan pernafasan, kanker, dan gangguan aktifitas sehari-hari, Suharto (1997)

Pada masa pertumbuhan anak usia remaja perlu dipantau keadaan gizinya, karena fisik memerlukan keadaan gizi yang baik dan seimbang, gizi adalah salah satu faktor yang mempengaruhi kebugaran jasmani. Semua aktifitas dapat dilakukan dengan baik jika anak mengkomsumsi makanan yang bergizi secara baik dan seimbang.

Selain latihan fisik (olahraga), Status gizi yang baik dapat meningkatkan kebugaran jasmani yang tinggi. Latihan fisik (olahraga) yang teratur serta diiringi dengan status gizi yang baik maka makin tinggi angka kebugaran jasmaninya. Gizi merupakan faktor luar (eksternal) yang dapat dikontrol dan dipraktekan dalam kehidupan sehari-hari. Para ahli telah membuktikan bahwa berbagai fungsi organ tubuh akan meningkat dengan nyata apabila diberikan gizi dan latihan fisik 
yang memadai. Makanan yang berperan tinggi akan berperan penting dalam pencapaian prestasi optimal, makin banyak ragam makanan yang dikonsumsi, makin terpenuhi gizi seseorang untuk mampu berprestasi tinggi, DepKes (1990).

Unsur-unsur yang terdapat dalam kebugaran jasmani adalah: 1) Daya Tahan (endurance), 2) Kekuatan Otot (muscle strength), 3) Tenaga ledak otot (muscle exploside power), 4) Kecepatan (speed), 5) Ketangkasan (agility), 6) Kelenturan (flexibility), 7) keseimbangan (balence), 8) Kecepatan reaksi (reaction time), 9) Koordinasi (coordination), 10) Ketepatan (accuracy).

Kebugaran jasmani dapat ditingkatkan melalui olahraga yang teratur, terprogram dan terencana dengan baik sehingga mempunyai kebugaran yang tinggi. Olahraga sangat dibutuhkan oleh tubuh sehingga mendapat membuat hidup lebih bergairah, kesehatan menjadi lebih baik, kebahagiaan dan kesinambungan.

Untuk menunjang dan melakukan segala kegiatan dan aktifitas fisik yang berlebih maka dibutuhkan kebugaran jasmani yang baik pula. Sasaran kebugaran jasmani bagi pelajar adalah untuk memotivasi dan meningkatkan kemampuan dan kemauan belajar yang berorentasi pada prestasi dalam keberhasilan studi. Oleh karena itu bagi setiap pelajar perlu mengetahui dan memahami cara untuk meningkatkan kebugaran jasmani agar mampu menjaga semangat belajar untuk keberhasilan setudi yang dilakukan.

Berdasarkan hasil survey yang dilakukan pada siswa-siswi Sekolah Menengah Atas (SMA) Merangin pada umumnya (dalam peneletian ini siswa putra SMA Negeri 10 Merangin) masih belum mengerti dan memahami tentang gizi khususnya status gizi yang dimiliki dan tingkat kebugaran jasmaninya. Berpedoman pada hal ini, keberadaan status gizi dengan kebugaran jasmani merupakan permasalahan yang penting untuk dikaji secara mendalam. Untuk itu perlu diadakan suatu penelitian yang mengkaji tentang status gizi dan kebugaran jasamani menggunakan lari 1000 meter.

Berdasarkan latar belakang masalah yang telah di uraikan diatas, maka masalah yang akan dibahas dalam penelitian ini dapat di identifikasikan sebagai berikut: Kurangnya informasi tentang status gizi setiap siswa SMA Negeri 10 Merangin, Kurangnya informasi tentang status gizi dan kebugaran jasmani pada siswa SMA Negeri 10 Merangin, Tidak pernah dilakukannya pengukuran status gizi dan tes kebugaran pada siswa SMA Negeri 10 Merangin

Berdasarkan identifikasi masalah di atas serta penelitian lebih terfokus dan mendalami maka penelitian ini hanya membahas tentang hubungan status gizi terhadap kebugaran jasmani menggunakan lari 1000 meter pada siswa Sekolah Menengah Atas Negeri 10 Merangin.

Berdasarkan batasan masalah diatas, maka rumusan masalah dalam penelitian ini adalah apakah terdapat hubungan status gizi terhadap kebugaran jasamani pada siswa Sekolah Menengah Atas Negeri 10 Merangin.

Penelitian ini bertujuan untuk mengetahui hubungan status gizi terhadap kebugaran jasmani pada siswa Sekolah Menengah Atas Negeri 10 Merangin.

Menurut Almatsier (2004) Status gizi adalah keadaan tubuh sebagai akibat konsumsi makanan dan penggunaan zat-zat gizi. Dibedakan antara status gizi buruk, kurang, baik, dan lebih. 
Menurut Irianto D.P, (2007), status gizi adalah eksperesi dari keadaan keseimbangan dalam bentuk variabel tertentu atau dapat dikatakan bahwa status gizi merupakan indikator baik buruknya penyedian makanan sehari-hari. Status gizi yang baik diperlukan untuk mempertahankan derajat kebugaran dan kesehatan, membantu pertumbuhan bagi anak serta menunjang pembinaan prestasi olahragawan.

Supariasa (2002), menyatakan bahwa status gizi adalah ekspresi dari keadaan keseimbangan dalam bentuk variabel tertentu, atau perwujudan dan nutriture dalam bentuk variabel tertentu.

Dari penjelasan di atas dapat di simpulkan bahwa Status gizi adalah ukuran dari keberhasilan seseorang yang mengkonsumsi makanan sehari-hari dengan kesesuaian yang dikonsumsi dengan gizi yang dibutuhkan oleh tubuh. Menurut Putra (2008), keadaaan kesehatan gizi dibagi menjadi tiga, yakni:

a. Gizi lebih (over nutritional state). Gizi lebih adalah tingkat kesehatan gizi yang diakibatkan konsumsi berlebihan. Ternyata, kondisi tersebut mempunyai tingkat kesehatan lebih rendah, meskipun berat badan ideal. Keadaan ini bisa menimbulkan penyakit-penyakit tertentu yang sering di jumpai pada orang gemuk, seperti penyakit kardiovaskuler ( menyerang jantung dan sistem pembuluh darah), hipertensi, diabetes melitus dan lainya.

b. Gizi baik (eunutritional state). Tingkat kesehatan gizi terbaik adalah kesehatan gizi optimum. Dalam kondisi ini, jaringan di dalam tubuh dipenuhi oleh semua zat yang dibutuhkan. Akibatnya, tubuh terbebas dari penyakit serta mempunyai daya kerja yang baik. Selain itu tubuh mempunyai daya tahan tinggi.

Gizi kurang (under nutrition). Gizi kurang adalah kondisi tubuh mengalami defisien berbagai nutrisi. Gejala-gejala penyakit defisien gizi adalah berat badan lebih rendah dari berat badan ideal serta persediaan zat-zat gizi bagi jaringan tidak mencukupi, sehingga menghambat fungsi jaringan tersebut.

Faktor-faktor yang mempengaruhi status gizi ada dua, yaitu faktor penyebab langsung dan tidak langsung. Faktor penyebab langsung yaitu asupan makan dan penyakit interaksi. Sedangkan faktor penyebab tidak langsung yaitu aktifitas fisik, faktor individu, faktor keluarga, lingkungan sekolah dan teman sebaya, tingkat sosial dan ekonomi, dan media massa.

Peran dan kedudukan Penilaian Status Gizi di dalam ilmu gizi adalah untuk mengetahui status gizi, yaitu ada tidaknya malnutrisi pada individu dan masyarakat. Mengapa penilaian status gizi menjadi penting? Karena terjadinya kesakitan dan kematian terkaitan dengan status gizi maka dengan melakukan penilaian status gizi pada individu atau masyarakat kita akan dapat mengetahui kelainan tersebut. Definisi Penilaian status gizi adalah interpretasi dari data yang didapatkan dengan menggunakan berbagai metode untuk mengindentifikasikan populasi dan individu yang beresiko atau dengan status gizi buruk.

Data penilian status gizi dapat dikumpulkan dengan berbagai cara. Pengumpulan data ini akan menjadi penting kedudukannya dalam penilaian status gizi karena akan sangat mempengaruhi hasil yang didapat yang pada akhirnya 
akan mempengaruhi juga informasi yang disampaikan. Hal penting lainya dalam penilaian status gizi adalah perencanaan dan penerapan.

Tujuan Peniaian Status Gizi

Penilaian status gizi bertujuan untuk:

1. Memberikan gambaran secara umum mengenai metode penilaian status gizi.

2. Memberikan penjelasan mengenai keuntungan dan kelemahan dari masing-masing metode yang ada.

3. Memberikan gambaran singkat mengenai pengumpulan data, perencanaan, dan implementasi untuk penilaian status gizi.

Tabel 1. Contoh Penilaian Status Gizi dengan Melihat Tanda Klinik, Departemen Gizi dan Kesehatan Masyarakat (2007)

\begin{tabular}{ll}
\hline \multicolumn{1}{c}{ Tanda klinik } & \multicolumn{1}{c}{ Kemungkinan kekurangan zat gizi } \\
\hline Pucat pada konjungtiva & Anemia \\
Bitot spot & Kurang vitamin A \\
Angular stomatitis & Riboflavin \\
Gusi berdarah & Kurang vitamin C \\
Pembesaran kelenjar gondok & Kurang yodium \\
Undema pada anak balita & Kurang energi protein \\
\hline
\end{tabular}

\section{Pemeriksaan Biofisik}

Metode biofisik adalah penentuan status gizi berdasarkan kemampuan fungsi dari jaringan dan perubahan struktur dan jaringan. Contoh pemeriksaan biofisik yang sering dilakukan adalah:

a) Pada kasus rabun senja dilakukan tes adaftasi dalam gelap (night blindness test)

b) Pemeriksaan phisycal performance (energy expenditure dan work capacity) yang dihubungkan dengan anemia.

c) Pemeriksaan ocular impression cytology, menempelkan kertas saring pada konjunctiva untuk melihat bentuk dari sel goblet, jika gepeng dan tidak ada inti, maka dikatakan kurang vitamin A.

\section{Pengukuran Antropometri}

Pengukuran antropometri adalah pengukuran terhadap dimensi tubuh dan komposisi tubuh. Ada beberapa pengukuran antropometri utama. Untuk lebih jelasnya dapat dilihat pada tabel 2 berikut.

Tabel 2. Pengukuran Antropometri yang Utama, Departemen Gizi dan Kesehatan Masyarakat (2007)

Pengukuran

\section{Komponen}

Jaringan utama yang di ukur

PJKR_

http://jurnal.unimed.ac.id/2012/index.php/jpehr/index 


\begin{tabular}{ccc}
\hline $\begin{array}{c}\text { Stature/tinggi } \\
\text { badan }\end{array}$ & $\begin{array}{c}\text { Kepala, tulang belakang, } \\
\text { tulang pinggul dan kaki }\end{array}$ & Tulang \\
\hline Berat badan & Seluruh tubuh & $\begin{array}{c}\text { Seluruh jaringan, khususnya } \\
\text { lemak, otot, tulang. Tulang } \\
\text { dan air }\end{array}$ \\
\hline $\begin{array}{c}\text { Lingkar } \\
\text { lengan }\end{array}$ & Lemak bawah kulit & $\begin{array}{c}\text { Otot (secara teknik lebih } \\
\text { sedikit digunakan dinegara } \\
\text { maju) }\end{array}$ \\
\cline { 2 - 3 } & Otot, tulang & $\begin{array}{c}\text { Lemak (lebih sering } \\
\text { digunakan secara teknik } \\
\text { dinegara maju) }\end{array}$ \\
Lipatan & Lemak bawah kulit, kulit & Lemak \\
lemak & &
\end{tabular}

Antropometri adalah pengukuran yang paling sering digunakan sebagai metode penilaian status gizi secara langsung untuk menilai dua masalah utama gizi, yaitu: (1) Kurang Energi Protein, khususnya pada anak-anak dan ilmu hamil, (2) obesitas pada semua kelompok umur. Penilaian status gizi dengan menggunakan antropometri ini memiliki kelebihan dan keterbatan.

Kelebihan:

1) Cepat, sehingga dapat dilakukan pada populasi yang besar

2) Objektif

3) Gradable, dapat dirangking apakah ringan, sedang, atau berat

4) Tidak memiliki rasa sakit pada responden

Keterbatasan:

1) Membutuhkan data yang relevan

2) Kesalahan yang muncul seperti kesalahan pada peralatan (belum dikalibrasi), kesalahan pada observer (kesalahan pengukuran, pembacaan dan pencatatan)

3) Hanya mendapatkan data pertumbuhan, obesitas, malnutrisi karena kurang energi dan protein, tidak dapat memperoleh informasi karena difisiensi zat gizi mikro.

Macam-macam pengukuran Antropometri yang bisa digunakan untuk melihat pertumbuhan adalah sebagai berikut.

a. Massa Tubuh

Berat badan adalah pengukuran antropometri yang paling sering digunakan meskipun sering terjadi kesalahan dalam pengukuran.

1. Berat Badan 
Berat badan mencerminkan jumlah protein, lemak, air, dan massa mineral tulang. Pada orang dewasa terdapat peningkatan jumlah lemak sehubungan dengan umur dan terjadi penurunan protein otot. Berat badan sewaktu lahir dapat digunakan sebagai indikator status gizi dengan cut off point $<2.500$ gram. Untuk menilai status gizi biasanya berat badan dihubungkan dengan pengkuran lainn, seperti umur dan tinggi badan.

b. Pengukuran Linear (panjang)

Dasar pengukuran linear adalah tinggi (panjang) atau stature dan mereflesikan pertumbuhan skeletal. Pengukuran linear lainnya seperti tulang biasa digunakan untuk tujuan tertentu. Minsalnya panjang lengan atas atau kaki.

1. Tinggi Badan

Pengukuran tinggi badan seseorang pada prinsipnya adalah mengukur jaringan tulang skeletal yang terdiri dari kaki, panggul, tulang belakang, dan tulang tengkorak. Penilaian status gizi pada umumnya hanya mengukur total tinggi (atau panjang) yang diukur secara rutin. Tinggi badan yang dihubungkan dengan umur dapat digunakan sebagai indikator status gizi masa lalu.

2. Panjang Badan

Panjang badan dilakukan pada balita yang berumur kurang dari dua tahun atau kurang dari tiga tahun atau kurang dari tiga tahun yang sukar untuk berdiri pada waktu pengumpulan data tinggi badan.

3. Lingkar Kepala

Pengukuran lingkar kepala biasa digunakan pada kedokteran anak digunakan untuk mendeteksi kelainan seperti hydrocephalus (ukuran kepala besar) atau microcephaly (ukuran kepala kecil). Untuk melihat pertumbuhan kepala balita dapat digunakan grafik Nellhaus.

4. Lingkar Dada

Pertumbuhan lingkar dada pesat sampai anak berumur 3 tahun sehingga biasa digunakan pada anak berusia 2-3 tahun.

5. Lingkar Lengan Atas

Lingkar lengan atas biasanya digunakan pada anak balita serta wanita usia subur.

6. Tinggi Lutut

Tinggi lutut erat kaitannya denagn tinggi badan sehingga data tinggi badan didapatkan dari tinggi lutut bagi orang tidak dapat berdiri atau manula.

7. Komposisi Tubuh

Otot dan lemak merupakan jaringan lunak yang bervariasi pada penderita kurang energi protein. Antropometri jaringan dapat dilakukan pada jaringan tersebut untuk menilai status gizi di masyarakat.

1. Lemak subkutan ( subcutaneous fat) 
Penilaian komposisi tubuh termasuk untuk mendapatkan informasi mengenai jumlah dan distribusi lemak dapat dilakukan dengan beberapa metode mulai dari yang paling sulit dilakukan sampai dengan metode yang relatif mudah untuk digunakan. Berikut ini adalah metode-metode yang bisa digunakan untuk menilai komposisi tubuh mulai dari yang paling sulit sampai dengan yang paling mudah.

a. Ultrasonik

b. Densitometri (melalui penempatan air pada densitometer atau underwater weighting).

c. Teknik Isotop Dilution

d. Nethoda radiological

e. Total Electrical Body Conduction

f. Antropometri (pengukuran berbagai tebal lemak menggunakan kaliper) Beberapa pengukuran tebal lemak dengan menggunakan kaliper:

a) Pengukuran triceps

b) Pengukuran bisep

c) Pengukuran suprailiak

d) Pengukuran subskapular

Menurut A. Kamisno (1996), Kebugaran jasmani adalah kesanggupan dan kemampuan seseorang untuk melakukan pekerjaan dengan efisien tanpa menimbulkan kelelahan yang berarti. Kebugaran jasmani adalah suatu aspek yaitu fisik dari dari kesegaran jasmani yang menyeluruh (total fitness) yang memberikan kesanggupan pada seseorang untuk menjalankan hidup yang produktif menyesuaikan diri dari tiap-tiap pembebanan fisik (phsykal fitness) dengan baik, Tri tunggal Setiawan (1996).

Kebugaran jasmani sangat penting bagi semua aspek kehidupan manusia, kebugaran jasmani mempunyai fungsi yang sangat penting dalam mensukseskan pembangunan. Kebugaran jasmani berfungsi pengembangan kesanggupan kerja bagi siapapun, sehingga dapat menyelesaikan tugas dengan baik tanpa mengalami kelelahan yang berarti, dan dengan kebugaran jasmani yang baik maka akan lebih muda dalam mencapai prestasi yang dinginkan. Daya tahan kerja dapat ditingkatkan dengan meningkatkan kebugaran jasmani, dan kebugaran jasmani dapat ditingkatkan dengan meningkatkan keseimbangan antara latihan-latihan olahraga yang dilakukan dengan reaksi organ tubuh, dengan latihan fisik secara fungsi kebugaran jasmani dapat dikelompokan berdasarkan tiga golongan:

a. Kebugaran jasmani bagi olahragawan untuk meningkatkan prestasi.

b. Kebugaran jasmani bagi karyawan atau pekerja untuk meningkatkan efisiensi dan produktivitas kerjanya.

Kebugaran jasmani bagi pelajar dan mahasiswa untuk mempertinggi kemampuan belajar. Kondisi fisik komponen yang sangat penting untuk meningkatkan kesegaran jasmani seseorang. Apabila seseorang dapat dikatakan

PJKR_

http://jurnal.unimed.ac.id/2012/index.php/jpehr/index 
mimiliki kondisi fisik yang baik, maka status setiap komponen harus dalam kategori baik.

Adapun komponen kondisi fisik menurut M. Sajoto (1995) ada 10 komponen yaitu sebagai berikut:

1. Kekuatan (strength), kekuatan adalah kemampuan kondisi fisik seseorang tentang kemampuannya dalam mempergunakan otot untuk menerima beban sewaktu bekerja M. Sajoto (1995).

2. Daya Tahan (endurance), daya tahan adalah keadaan kondisi tubuh yang mampu bekerja untuk waktu yang lama, tanpa mengalami kelelahan yang berlebihan setelah melakukan pekerjaan tersebut Harsono (1988).

3. Daya Otot (musculer endurence), daya ledak adalah kemampuan seseorang untuk mempergunakan kekuatan maksimal yang dikerahkan dalam waktu yang sependek-pendeknya. Dalam hal ini dapat dinyatakan bahwa daya otot sama dengan kekuatan kali kecepatan M. Sajoto (1995).

4. Kecepatan (speed), kecepatan adalah kemampuan seseorang untuk mengerjakan gerakan berkesinambungan dalam bentuk yang sama dalam waktu yang sesingkat-singkatnya, seperti lari cepat, pukulan dalam tinju, balap sepeda dan lain-lain. dalam hal ini ada kecepatan gerak dan ada kecepatan explosive M. Sajoto (1995). Kecepatan adalah kemampuan gerak-gerak sejenis secara berturut-turut dalam waktu yang sesingkat-singkatnya Harsono (1998).

5. Daya lentur (fleksibility), daya lentur adalah efektifitas seseorang dalam menyesuaikan diri untuk segala efektifitas penguluran tubuh. Hal ini akan sangat mudah ditandai dengan tingkat fleksibilitas persendian dalam seluruh tubuh. Untuk pemeliharaan kelenturan tubuh maka kita harus menggerakan persendian kita pada daerah yang maksimal secara teratur Sudoso Sumosarjdono (1992).

6. Kelincahan (agility), kelincahan adalah kemampuan sseorang untuk mengubah posisi pada area tertentu. Seseorang mampu mengubah satu posisi yang berbeda dalam kecepatan yang tinggi dengan kordinasi yang baik berarti kelincahan cukup baik M. Sajoto (1995).

7. Koordinasi (cordination), koordinasi adalah kemampuan seseorang untuk mengintegrasikan bermacam-macam gerakan tunggal secara efektif. Misalnya dalam bermain tenis, seseorang akan kelihatan memiliki koordinasi yang baik bila dapat bergerak kearah bola sambil mengayun raket kemudian memukul M.Sajoto (1995).

PJKR_

http://jurnal.unimed.ac.id/2012/index.php/jpehr/index 
8. Kesimbangan (balance), keseimbangan adalah kemampuan seseorang mengendalikan organ-organ syaraf otot seperti dalam handstand atau dalam mencapai keseimbangan M, Sajoto (1996).

9. Ketepatan (accuraty), ketepatan adalah kemampuan seseorang untuk mengendalikan gerakan-gerakan bebas terhadap suatu sasaran. Sasaran ini merupakan suatu jarak yang mungkin suatu obyek yang langsung yang harus dikenai oleh salah satu bagian tubuh M. Sajoto (1995).

10. Reaksi (reaction), reaksi adalah kemampuan seseorang untuk bergerak secepatnya dalam menanggapi rangsangan yang ditimbulkan lewat indera, syaraf atau filling lainya seperti dalam mengantisipasi datangnya bola harus ditangkap dan lain-lain M. Sajoto (1995).

\section{Metode}

Pelaksanaan penelitian dilakukan dengan pengumpulan data yang dilaksanakan di lapangan Sekolah Menengah Atas Negeri 10 Merangin yang beralamat di Jl. Muara siau - Jangkat Kec. Muara Siau, Kabupaten Merangin. Penelitian ini dilaksanakan dari tanggal 09 Oktober sampai 24 November 2017. Metode Penelitian yang digunakan akan mempengaruhi keberhasilan suatu penelitian. Oleh karena itu penggunaan metode penelitian harus tepat dan mengarah pada tujuan penelitian, agar hasil yang diperoleh sesuai dengan hasil yang di harapkan. Penelitian ini merupakan penelitian korelasional, yang hendak menyelidiki ada tidaknya hubungan antara variabel bebas dengan variabel terikat. Yang menjadi variabel bebas dalam penelitian ini adalah Status Gizi (X) sedangkan variabel terikatnya adalah Kebugaran jasmani (Y).

Populasi penelitian ini adalah siswa laki-laki SMA Negeri 10 Merangin tahun ajaran 2015/2016 yang terdiri dari 136 orang siswa. Sampel yang akan digunakan dalam penelitian ini adalah sampel acak disebut juga Random sampling adalah dimana sampel yang diambil merupakan populasi homogen yang hanya mengandung satu ciri. Karena jumlah populasi siswa Laki-laki SMA Negeri 10 Merangin sebanyak 136 orang makan peneliti mengambil 22\% dari jumlah siswa jadi sampel yang diambil berjumlah 30 orang siswa dengan teknik acak.

Instrumen yang digunakan dalam penelitian ini terdiri atas dua macam yaitu: Tes Antropometri Gizi dan Tes lari 1000 meter, langkah selanjutnya adalah menganalisis data dari hasil penelitian yang telah dilakukan.

\section{Pembahasan}

Berdasarkan dari uraian yang telah dikumpulkan sebelumnya maka didalam bab ini akan disajikan analisa pembahasan yang diperoleh dalam penelitian ini. Hasil penelitian ini akan digambarkan sesuai dengan tujuan dan hipotesis yang akan diajukan sebelumnya. Gambar dari data dalam kelompok dapat dilihat pada deskripsi berikut ini:

Tabel 3. Deskripsi Data Penelitian

\begin{tabular}{lllllll}
\hline Data & N & $\sum$ & Mean & Sd & Max & Min \\
\hline
\end{tabular}

PJKR_

http://jurnal.unimed.ac.id/2012/index.php/jpehr/index 


\begin{tabular}{lllllll}
\hline Lari 1000 Meter & 30 & 115,99 & 5,2 & 3,42 & 8,32 & 3,12 \\
\hline Status Gizi & 30 & 607,03 & 20,23 & 5,72 & 28,93 & 15,05 \\
\hline
\end{tabular}

Dari tabel diatas maka dapat dijelaskan untuk data Lari 1000 Meter dengan jumlah sampel 30 orang kemudian didapatkan jumlah nilai 115,99 dengan ratarata nilai 5,2 dan standar deviasi 3,42 nilai tertinggi yang didapatkan 8,32 dan terendah 3,12. Untuk data Status Gizi dengan jumlah sampel sampel 30 orang kemudian didapatkan jumlah nilai 607,03 dengan rata-rata nilai 20,23 dan standar deviansi 5,72 nilai tertinggi yang didapatkan 28,93 dan terendah 15,05.

Analisis Data

Sebelum dilakukan uji hipotesis untuk melihat kontribusi dari variabel maka harus dilakukan terlebih dahulu uji normalitas kedua data tersebut maka uji normalitas data dapat digambarkan sebagai berikut:

Tabel 4. Uji Normalitas

\begin{tabular}{lllll}
\hline Data & N & Lo & Ltabel & Keterangan \\
\hline Lari 1000 Meter & 30 & $\mathbf{0 , 1 5 7 7}$ & 0,161 & Normal \\
\hline Status Gizi & 30 & $\mathbf{0 , 1 5 9 4}$ & 0,161 & Normal \\
\hline
\end{tabular}

Untuk uji normalitas Lo < Ltabel, maka data dari kedua variabel memiliki distribusi data yang normal karena, untuk data lari 1000 meter Lo $(0,1577)<$ Ltabel $(0,161)$, data status gizi Lo $(0,1594)<$ Ltabel $(0,161)$.

Untuk uji hipotesis, melihat dari hubungan variabel $\mathrm{x}$ dengan variabel $\mathrm{y}$ maka dapat didiskripsikan sebagai beriut:

Tabel 5. Uji Korelasi X dan Y

\begin{tabular}{llllll}
\hline $\mathbf{N}$ & $\mathbf{X}$ & $\mathbf{Y}$ & $\mathbf{X}^{\mathbf{2}}$ & $\mathbf{Y}^{\mathbf{2}}$ & $\mathbf{X Y}$ \\
\hline $\mathbf{3 0}$ & 115,99 & 607,03 & 786,95 & 11333,53 & 2994,37 \\
\hline
\end{tabular}

$r x y=1,142$

$$
r X_{1} Y=\frac{n \cdot \sum X_{1} Y-\left(\sum X_{1}\right)\left(\sum \mathrm{Y}\right)}{\sqrt{\left\{\left(n \sum \mathrm{X}_{1}^{2}-\left(\sum X_{1}\right)^{2}\left(\mathrm{n} \sum \mathrm{Y}^{2}-\left(\sum \mathrm{Y}\right)^{2}\right)\right\}\right.}}
$$

Dari perhitungan hasil analisis data antara lari 1000 meter dengan status gizi, diketahui $r_{x l y}=1,142$ kemudian data tersebut diakumulasi terhadap interprestasi dengan kategori rendah.

Setelah dilakukan koefesien korelasi kemudian dapat koefesien korelasinya dengan uji-t.

$$
\begin{aligned}
& t_{\text {hitung }}=\frac{r \sqrt{n-2}}{\sqrt{1-r^{2}}} \\
& t_{\text {hitung }}=\frac{1,142 \sqrt{30-2}}{\sqrt{1-(1,142)^{2}}} \\
& t_{\text {hitung }}=10,9840
\end{aligned}
$$

PJKR_

http://jurnal.unimed.ac.id/2012/index.php/jpehr/index 
Distribusi (table $\mathrm{t})$ untuk $\alpha=0,05$ dan derajat kebebasan $(\mathrm{dk}=\mathrm{n}-2)$ kaidah keputusan jika $t_{\text {hitung }}>t_{\text {tabel }}$ berarti signifikan, sebaliknya jika $t_{\text {hitung }}<t_{\text {tabel }}$ berarti tidak signifikan, berdasarkan hasil yang didapat $t_{\text {hitung }} 10,9840$ dengan $t_{\text {tabel }}$ 1,70113 dengan demikian $t_{\text {hitung }}$ lebih besar dari $t_{\text {tabel }}$ maka dapat disimpulkan bahwa terdapat hubungan lari 1000 meter dan status gizi pada siswa SMAN 10 Merangin.

\section{Simpulan}

Lari 1000 meter adalah salah satu rangkaian dari Tes Kesegaran Jasmani, lari 1000 meter merupakan salah satu tolak ukur untuk mengetahui tingkat Kesegaran Jasmani siswa yang berumur 16-19 tahun. Karena lari 1000 meter mengukur daya tahan jantung, peredaran darah dan pernapasan. Seseorang yang tingkat kesegarannya tinggi akan menpunyai daya tahan jantung, peredaran darah dan pernapasan yang baik pula.

Sedangkan status gizi adalah keadaan tubuh sebagai akibat konsumsi makanan, dan penggunaan zat-zat gizi, dibedakan antara status gizi buruk, kurang, baik dan lebih. Ada berapa faktor-faktor yang mempengaruhi status gizi antara lain faktor External adalah yang meliputi pendapatan, pendidikan, pekerjaan dan budaya. Faktor internal meliputi kondisi usia, kondisi fisik dan infeksi.

Ukuran dari keberhasilan seseorang yang mengkonsumsi makanan seharihari dengan kesesuaian yang dikonsumsi dengan gizi yang dibutuhkan oleh tubuh adalah status gizi.

Kaidah keputusan jika $t_{\text {hitung }}>t_{\text {tabel }}$ berarti signifikan, sebaliknya jika $t_{\text {hitung }}$ $<\mathrm{t}_{\text {tabel }}$ berarti tidak signifikan, berdasarkan hasil yang didapat $t_{\text {hitung }} 10,9840$ dengan $t_{\text {tabel }}$ 1,70113 dengan demikian $t_{\text {hitung lebih besar dari tabel maka dapat }}$ disimpulkan bahwa terdapat hubungan lari 1000 meter dan status gizi pada siswa SMAN 10 Merangin.

\section{Rujukan}

Almatsier, 2004. Prinsip Dasar Ilmu Gizi. Jakarta: PT Gramedia Pustaka Utama Depdiknas, 2003. Tes Kesegaran Jasmani Indonesia (untuk anak umur 16-19 tahun). Jakarta: pusat pengembangan Kualitas Jasmani

Departemen Gizi dan Kesehatan Masyarakat Fakultas Kesehatan Masyarakat Universitas Indonesia, 2007. Gizi dan Kesehatan Masyarakat Jakarta: PT. Raja Grafindo Persada

Depkes Kesejahteraan Sosial RI, 2000. Pedoman Pelatihan Gizi Olahraga Untuk Prestasi, Jakarta: Departemen Kesehatan dan Kesejahteraan Sosial RI, Direktorat Jenderal Kesehatan Masyarakat, Direktorat Gizi Masyarakat

Depertemen Pendidikan dan Kebudayaan Pusat Kesegaran Jasmani dan Rekreasi, 1986. Tes Kesegaran Jasmani Indonesia. Jakarta: Debdikbud

Fillah Fithra Dieny, 2010. Permasalahn Gizi Pada Remaja Putri. Yoyakarta: Graha Ilmu

PJKR_

http://jurnal.unimed.ac.id/2012/index.php/jpehr/index 
Irianto, D.P, 2007. Panduan Gizi Lengkap Keluarga dan Olahragawan. Yogyakarta: Penerbit Andi

Soediaoetama, 2009. Ilmu Gizi Untuk Mahasiswa dan Propesi. Jakarta: Dian Rakyat

Wiarto, 2011. Ilmu Gizi Dalam Olahraga. Jakarta: Gosyen Publisthing 